\title{
Prevalensi Konsumsi Rokok Pria Usia 18 - 64 Tahun dengan Hipertensi di Desa Susut, Kabupaten Bangli Bali Tahun 2014
}

\author{
Bianca Jeanne \\ Program Studi Pendidikan Dokter, Fakultas Kedokteran Universitas Udayana \\ (jeannesadeli@gmail.com)
}

Diterima: 4 Maret 2016. Disetujui: 28 Maret 2016. Diterbitkan: Juni 2016

\begin{abstract}
ABSTRAK
Hipertensi merupakan masalah klasik yang berkontribusi dalam meningkatkan morbiditas dan mortalitas akibat komplikasinya. Hipertensi yang ditangani dengan baik mengurangi risiko stroke, penyakit jantung koroner, gagal jantung kongestif, dan kematian secara signifikan. Faktor-faktor yang mempengaruhi terjadinya hipertensi dibagi menjadi dua kelompok besar: faktor yang tidak dapat dimodifikasi seperti jenis kelamin, usia, dan faktor genetic, dan faktor yang dapat dmodifikasi seperti pola makan, kebiasaan olahraga dan lain-lain. Untuk terjadinya hipertensi perlu peran faktor risiko ini bersama-sama, dengan kata lain salah satu faktor risiko saja tidak cukup menyebabkan hipertensi. Merokok telah lama dikaitkan dengan tingginya jumlah morbiditas dan mortalitas pada penyakit kardiovaskular. la bekerja bersama dengan hipertensi dan dislipidemia untuk meningkatkan kejadian infarct miokard. Studi cross sectional deskriptif dilakukan terhadap 89 masyarakat di Desa Susut Kabupaten Bangli, yang di pilih degan metode non probability sampling (convenience sampling). Masing masing sampel dilakukan pengukuran untuk mendapatkan data tekanan darah, berat badan serta tinggi badan. Wawancara dilakukan untuk mendapatkan data karakteristik responden serta data mengenai pola konsumsi rokok pada pria hipertensi di desa Susut, Kabupaten Bangli. Data di analisis secara deskriptif. Hasil analisis data menggambarkan bahwa keseluruhan sampel mengalami hipertensi yaitu sejumlah 33 orang (37\%) dan sisanya sebanyak 56 orang (63\%) tidak mengalami hipertensi. Status merokok laki-laki hipertensi usia 18-64 tahun di desa Susut, Bangli didapatkan cenderung merupakan perokok aktif $(48,4 \%)$. Tingkat keparahan merokok cenderung merupakan perokok ringan $(88,8 \%)$. Jenis rokok yang dikonsumsi semua penderita hipertensi adalah rokok filter (100\%). Lama mantan perokok cenderung kurang dari 10 tahun (80\%).

Kata kunci: Hipertensi, merokok, prevalensi, cross sectional
\end{abstract}

\section{Prevalence and Cigarette Consumption Pattern in Men with Hypertension Aged 18-64 Years Old in Susut Village, Bangli Regency Bali 2014}

\section{ABSTRACT}

Hypertension is a classic problem that contributes to increased morbidity and mortality due to its complications. A good management of hypertension can reduce the risk of stroke, coronary heart disease, congestive heart failure, and death significantly. Factors that influence the occurrence of hypertension were divided into two major group; unmodifying factors such as sex, age, and genetic factors, and modifying factors such as diet, exercise habits and others. Hypertension happened due to the combination of these risk factors together, in other words, one risk factor alone is not sufficient to cause hypertension. Smoking has long been associated with high numbers of morbidity and mortality in cardiovascular disease. It works together with hypertension and dyslipidemia to increase the incidence of myocardial infarct. A descriptive cross-sectional study conducted on 89 
people in the Susut village of Bangli, which is selected with non-probability sampling methods (convenience sampling). Each sample was measured to obtain the data of blood pressure. Interviews were conducted to obtain data about the characteristics of respondents and pattern of cigarette consumption in men with hypertension in Susut village, Bangli Regency. Data were analyzed descriptively. Results of the data analysis shows that the overall sample have hypertension that is a number of 33 people (37\%) and the remaining 56 people (63\%) did not have hypertension.And for the pattern of cigarrete consumption in hypertensive men aged 18-24 years in Susut village, Bangli obtained tend to be current smokers (48.4\%). The severity of cigarrete consumption tend to be light smokers (88.8\%). All types of cigarettes consumed is filter type (100\%) and for years of cessation in ex-smokers tend to be less than 10 years (80\%).

Key words: Hypertension, smoking, prevalence, cross sectional

\section{Pendahuluan}

Hipertensi merupakan masalah klasik yang berkontribusi dalam meningkatkan morbiditas dan mortalitas akibat komplikasinya. Hipertensi yang ditangani dengan baik mengurangi risiko stroke, penyakit jantung koroner, gagal jantung kongestif, dan kematian secara signifikan. ${ }^{1}$

Prevalensi hipertensi lebih tinggi pada laki-laki dibandingkan pada wanita dalam Faktor-faktor yang mempengaruhi terjadinya hipertensi dibagi menjadi dua kelompok besar: faktor yang tidak dapat dimodifikasi seperti jenis kelamin, usia, dan faktor genetic, dan faktor yang dapat dimodifikasi seperti pola makan, kebiasaan olahraga dan lain-lain. Untuk terjadinya hipertensi perlu peran faktor risiko ini bersamasama, dengan kata lain salah satu faktor risiko saja tidak cukup menyebabkan hipertensi. Selain melalui obat - obatan, pengendalian faktor risiko juga diperlukan dalam pengobatan hipertensi. ${ }^{2}$

Merokok telah lama dikaitkan dengan tingginya jumlah morbiditas dan mortalitas pada penyakit kardiovaskular. la bekerja bersama dengan hipertensi dan dislipidemia untuk meningkatkan kejadian infarct miokard. ${ }^{3}$

Selain durasi, risiko perokok terbesar tergantung pada jumlah rokok yang dihisap per hari. Seseorang lebih dari satu pak rokok sehari untuk 2 kali lebih rentan terhadap hipertensi dibandingkan pada mereka yang tidak merokok . ${ }^{4}$

Merokok dapat meningkatkan tekanan darah secara signifikan dengan merangsang sistem saraf simpatik. Efek ini yang dimediasi oleh nikotin, suatu agonis adrenergik, dapat meningkatkan tekanan darah sekitar $10-25 \mathrm{mmHg}$ untuk setiap kelompok usia di bawah 54 tahun. Pada usia 5564, persentase laki-laki dan wanita adalah sama. Angka ini berubah setelah usia 64, dimana persentase yang lebih tinggi adalah wanita hipertensi dibandingkan laki-laki ${ }^{1}$

Penelitian yang dilakukan Anand di Asia Tenggara menunjukkan bahwa Indonesia berada di peringkat kedua jumlah tertinggi penderita hipertensi. ${ }^{2}$

rokok dan meningkatkan detak jantung selama sekitar 5-20 kali per menit. Efek ini berlangsung setidaknya 15 menit setelah merokok. ${ }^{4,5}$

Selain efeknya terhadap tekanan darah dan hipertensi, merokok juga merusak fungsi pembuluh darah dan meningkatkan kekakuan arteri, peradangan, serta ketidakseimbangan yang agregasi dan anti-agregasi faktor yang menyebabkan kejadian kardiovaskular. ${ }^{6}$

Terbaru WHO Data melaporkan bahwa Indonesia merupakan salah satu negara dengan prevalensi perokok tertinggi di dunia, dengan persentase 46,8 persen laki-laki dan 3,1 persen wanita berusia 10 tahun atau lebih. ${ }^{6}$ Rokok sebenarnya bertanggung jawab untuk lebih dari 200.000 kematian setiap tahun di Indonesia. ${ }^{3,5}$ Dan karena merokok dan hipertensi adalah dua faktor independen yang kuat yang juga dapat bekerja sama sebagai penyebab utama kejadian kardiovaskular, penulis ingin melihat kebiasaan merokok di kalangan laki-laki hipertensi sekitar usia 16-64 tahun. Oleh karena itu sangat penting untuk mengetahui pola konsumsi rokok pada penderita hipertensi, karena selain sebagai faktor resiko, namun rokok juga bekerja bersamaan 
dengan hipertensi dalam menyebabkan komplikasi lain terutama penyakit vaskular.

Berdasarkan latar belakang permasalahn diatas, peneliti meneliti mengenai prevalensi hipertensi serta pola konsumsi rokok pada laki-laki hipertensi usia 18-64 tahun di wilayah kerja Puskesmas Susut I, kecamatan Susut 1, Bangli.

\section{METODE}

Penelitian ini menggunakan rancangan penelitian cross sectional deskriptif yaitu dilakukan satu kali pengumpulan data Sampel penelitian diambil dengan metode non probability sampling (convenience sampling).

Populasi dalam penelitian ini adalah lakilaki berusia antara 18-64 tahun yang berdomisili di desa Susut, Kecamatan Susut, Kabupaten Bangli Pengumpulan data dilakukan menggunakan structured questionaire dalam Bahasa Indonesia. Kuesioner diuji coba terlebih dahulu pada sejumlah responden. Data yang dikumpulkan meliputi data karakteristik responden, data laki-laki usia 18-64 tahun penderita hipertensi, dan data pola konsumsi rokok pada laki-laki usia 18-64 tahun dan data tabulasi silang antara penderita hipertensi dan pola konsumsi rokok mereka. Data karakteristik responden meliputi usia, status pernikahan, pekerjaan, penghasilan, dan pendidikan. Data pola konsumsi rokok meliputi, status merokok, tingkat keparahan merokok, jenis rokok, dan lama berhenti merokok.

Data yang telah dikumpulkan kemudian diolah dan dianalisis secara deskriptif. Data proporsi dianalisis menggunakan chi square. Data yang tidak lengkap di eksklusi. Data yang telah diolah disajikan dalam bentuk table.

\section{HASIL PENELITIAN}

Berdasarkan penelitian yang dilaksanakan di Desa Susut, Kecamatan Susut, Kabupaten Bangli selama 3 minggu, didapatkan 89 sampel yang memenuhi kriteria inklusi. Subjek penelitian didapatkan dari data populasi yang berjumlah 2000 orang.

\section{Gambaran Karakteristik Sosiodemografik Subjek Penelitian}

Subjek penelitian merupakan warga laki-laki Desa Susut, Kecamatan Susut, Kabupaten Bangli yang berjumlah 89 orang. Responden usia remaja akhir sebanyak 5 orang (5,6\%), usia dewasa sebanyak 43 orang $(48,3 \%)$ dan usia lansia sebanyak 41 orang (46,1\%). Responden yang sudah menikah sebanyak 83 orang $(93,3 \%)$ dan yang belum menikah sebanyak 6 orang $(6,7 \%)$. Sebanyak 5 orang $(5,6 \%)$, usia dewasa sebanyak 43 orang $(48,3 \%)$ dan usia lansia sebanyak 41 orang $(46,1 \%)$. Responden dengan pekerjaan sebagai petani/buruh sebanyak 49 orang $(55,1 \%)$, sebagai PNS 23 orang $(25,8 \%)$ dan sebagai pegawai swasta sebanyak 17 orang(19,1\%).

Tabel 1. Distribusi Karateristik subjek Penelitian di Desa Susut, Kabupaten Bangli tahun 2014

\begin{tabular}{ccc}
\hline Karakteristik & $\begin{array}{c}\text { Jumlah } \\
\text { (total=8 } \\
9)\end{array}$ & $\begin{array}{c}\text { Persentase } \\
(\%)\end{array}$ \\
\hline $\begin{array}{c}\text { Usia (tahun) } \\
\text { Remaja akhir (17-25 } \\
\text { thn) }\end{array}$ & 5 & 5,6 \\
Dewasa (26-45 thn) & 43 & 48,3 \\
Lansia (46-65 thn) & 41 & 46,1 \\
Status Pernikahan & & \\
Menikah & 83 & 93,3 \\
Belum Menikah & 6 & 6,7 \\
Pekerjaan & & \\
Petani/Buruh & 49 & 55,1 \\
PNS & 23 & 25,8 \\
$\quad$ Swasta & 17 & 19,1 \\
Penghasilan & & \\
Rendah (<UMR) & 59 & 66,3 \\
Cukup(>UMR) & 30 & 33,7 \\
Pendidikan & & \\
Rendah & 26 & 29,2 \\
Menengah & 49 & 55,1 \\
Tinggi & 14 & 15,7 \\
\hline
\end{tabular}

Responden dengan penghasilan dibawah UMR sebanyak 59 orang $(66,3 \%)$ dan penghasilan diatas UMR sebanyak 30 orang $(33,7 \%)$ laki-laki dengan pendidikan rendah sebanyak 26 orang $(29,2 \%)$, pendidikan menegah 49 orang (55,1\%) dan pendidikan tinggi sebanyak 14 orang $(15,7 \%)$.

\section{Prevalensi Hipertensi dan Tidak Hipertensi}


Berdasarkan 89 sampel penelitian, terdapat 33 orang (37\%) mengalami hipertensi dan sisanya sebanyak 56 orang (63\%) tidak hipertensi.

Tabel 2. Prevalensi Hipertensi dan Tidak Hipertensi Pada Penduduk di Desa Susut Tahun 2014

\section{Pola Konsumsi Rokok penderita Hipertensi}

Pada status merokok, ditemukan bahwa 48,4\% penderita hipertensi merupakan perokok aktif. Prevalensi hipertensi paling rendah adalah pada perokok pasif yaitu sebesar $9,1 \%$

Pada jenis rokok yang dikonsumsi oleh perokok aktif, didapatkan hasil bahwa seluruh subjek yang menderita hipertensi mengonsumsi rokok filter. Kategori perokok ringan mempunyai persentase tertinggi pada penderita hipertensi sebanyak 16 orang (88.8\%) daripada kategori perokok sedang dan berat.

Subjek penelitian yang merupakan mantan perokok, didapatkan bahwa penderita hipertensi pada subjek dengan lama berhenti merokok <5 tahun berjumlah 2 subjek (40\%). Lama berhenti Merokok dengan durasi 5-10 tahun didapatkan 2 subjek (40\%) yang mengalami hipertensi. Untuk durasi berhenti merokok selama 10-15 tahun tidak ditemukan penderita hipertensi. Pada mantan prokok dengan lama berhenti merokok $>15$ tahun ditemukan 1 orang subjek (20\%) yang mengalami hipertensi

Tabel 3. Penderita Hipertensi Berdasarkan Status Merokok

\begin{tabular}{lc} 
Status Merokok & Hipertensi \\
\hline Tidak Merokok & 9 \\
& $(27,3 \%)$ \\
\hline Perokok Aktif & 16 \\
& $(48,4 \%)$ \\
\hline Mantan Perokok & 5 \\
& $(15,2 \%)$ \\
\hline Perokok Pasif & 3 \\
& $(9,1 \%)$ \\
\hline Total & 33 \\
& $(100 \%)$ \\
\hline
\end{tabular}

Tabel 4. Penderita hipertensi berdasarkan tingkat keparahan merokok

\begin{tabular}{llc}
\hline Kategori Perokok & \multicolumn{2}{l}{ Hipertensi } \\
\hline - Perokok Ringan & $\begin{array}{l}16 \\
(88.8 \%)\end{array}$ \\
\hline Tekanan darah & Jumlah & Persentase \\
(n) & (\%) \\
\hline Hipertensi & 33 & 37 \\
\hline Tidak Hipertensi & 56 & 63 \\
\hline Total & 89 & 100 \\
\hline - Perokok Sedang & 2 & \\
\hline - Perokok Berat & $(11.2 \%)$ & \\
\hline & 0 & \\
\hline
\end{tabular}

Tabel 5. Penderita Hipertensi Berdasarkan Jenis Rokok Perokok Aktif

Jenis Rokok Hipertensi

\begin{tabular}{lc}
\hline Filter & 16 \\
& $(100 \%)$ \\
\hline Non-Filter & 0 \\
& $(0 \%)$ \\
\hline Total & 16 \\
& $(100 \%)$ \\
Tabel 5.6 Penderita Hipertensi Berdasarkan Lama & \\
Berhenti Merokok & Hipertensi \\
Lama Berhenti Merokok & 2 \\
\hline$<5$ tahun & $(40 \%)$ \\
\hline $5-<10$ tahun & 2 \\
& $(40 \%)$ \\
\hline $10-<15$ tahun & 0 \\
\hline$>15$ tahun & $(0 \%)$ \\
\hline
\end{tabular}


Total

$(100 \%)$

\section{PEMBAHASAN}

Gambaran Karakteristik Penduduk Desa Susut, Kecamatan Susut, Kabupaten Bangli

Berdasarkan hasil yang diperoleh dari penelitian di Desa Susut, Kecamatan Susut, Kabupaten Bangli, didapatkan 89 subjek penelitian berjenis kelamin laki-laki yang terdiri dari remaja akhir, dewasa, dan lansia. Sesuai dengan kriteria inklusi yang sudah ditetapkan, subjek penelitian merupakan penduduk yang berusia remaja akhir sampai lansia, yaitu 18-64 tahun, didapatkan 89 orang sampel yang memenuhi syarat. Subjek penelitian didominasi dengan usia dewasa (48,3\%) yang sudah berstatus menikah $(93,3 \%)$, berpendidikan rendah $(29,2 \%)$, dengan pekerjaan sebagai petani/buruh $(55,1 \%)$ dan berpenghasilan rendah (66,3\%).

\section{Distribusi Kejadian Hipertensi dan Tidak Hipertensi}

Data yang diperoleh dari penelitian ini menunjukkan bahwa lebih dari sepertiga dari keseluruhan sampel mengalami hipertensi yaitu sejumlah 33 orang (37\%) dan sisanya sebanyak 56 orang (63\%) tidak mengalami hipertensi. Angka tersebut tergolong cukup tinggi untuk prehipertensi dan hipertensi di wilayah Puskesmas Susut I, dimana angka kejadian hipertensi selalu termasuk dalam sepuluh besar penyakit yang sering terjadi di wilayah Puskesmas Susut I. Tingginya kejadian prehipertensi pada usia dewasa dapat digunakan sebagai acuan untuk mengetahui kemungkinan seseorang terkena hipertensi di usia lanjut. Seorang individu dengan prehipertensi saat usia dini memiliki risiko tiga kali lipat untuk terkena hipertensi pada usia lanjut dibandingkan dengan orang normal di usia yang sama ${ }^{1,7}$

Kasus prehipertensi di dominasi oleh usia lansia (51,2\%) dan kasus hipertensi cenderung pada dewasa $(39,5 \%)$ walau perbedaan angka ini tidak telalu jauh dengan usia lansia $(34,1 \%)$. Hal in sesuai dengan penelitian lain yang menunjukkan bahwa resiko hipertensi semakin bertambah seiring dengan bertambahnya usia. ${ }^{8,9}$ Namun usia remaja akhir juga didapatkan yaitu sekitar $60 \%$ mengalami prehipertensi dan sisanya mengalami hipertensi(40\%). Angka ini cukup mengkhawatirkan mengingat proses kronis dari hipertensi sudah dimulai sejak usia remaja akhir. Namun dikarenakan jumlah sample pada remaja akhir kecil, yaitu 5 orang dan tidak sesuai dengan perbandingan usia dewasa dan lansia, sehingga perlu dilakukan penelitian lebih lanjut mengenai fenomena ini.

Pada penelitian ini didapatkan persentase hipertensi meningkat dengan semakin tingginya tingkat pendidikan. Hubungan hipertensi dengan tingkat pendidikan menunjukkan hasil yang bervariasi pada beberapa penelitian, namun rendahnya tingkat pendidikan berhubungan dengan kurangnya kesadaran akan menderita hipertensi dan tingkat kontrol hipertensi yang lebih buruk dibanding tingkat pendidikan yang lebih tinggi. ${ }^{10,11}$

Pada penelitian ini didapatkan sebanyak 31 laki-laki $(37,3 \%)$ yang telah menikah dan 2 laki-laki $(33,3 \%)$ yang belum menikah menderita hipertensi. Hal ini tidak sesuai dengan teori dimana berdasarkan status pernikahan prevalensi penderita hipertensi lebih tinggi pada subjek yang belum menikah atau bercerai dibanding yang sudah menikah. Mereka juga memiliki kesadaran dan kontrol hipertensi yang lebih baik dibanding kelompok lain. 5,12 Namun hal ini mungkin dikarenakan perbedaan jauh antara sample yang telah menikah dan belum menikah yaitu 83 orang dan 6 orang sehingga kurang merepresentasikan kejadian sebenarnya di masyarakat.

Berdasarkan pekerjaan, sebanyak 17 petani (34,7\%), 9 PNS (39,1\%), 7 pegawai swasta (41,2 \%) yang menderita hipertensi. Berdasarkan penghasilan, didapatkan 22 orang $(37,3 \%)$ dengan penghasilan dibawah UMR dan 11 orang $(36,7 \%)$ dengan penghasilan diatas UMR menderita hipertensi. Hubungan hipertensi dan jenis pekerjaan dipengaruhi oleh banyak faktor seperti tingkat stress, aktivitas. Berdasarkan penghasilan, tingkat hipertensi menurun dengan semakin tingginya penghasilan dimana sesuai dengan hasil penelitian. $^{7}$

Sedangkan untuk gambaran konsumsi rokok pada perokok aktif, berdasarkan hasil semua penderita mengonsumsi rokok filter (100\%) 
daripada rokok jenis non-filter. Untuk gambaran konsumsi mantan perokok, didominasi oleh rokok jenis filter. Yang mungkin disebakan karena tidak populernya lagi rokok non-filter.

Kemudian untuk melihat gambaran tingkat keparahan pada subjek penelitian, dengan berdasarkan indeks Brinkmann (jumlah batang rokok yang dikonsumsi per hari $x$ tahun lama merokok), ${ }^{13}$ Dimana pada penelitian ini, perokok ringan mempunyai persentase tertinggi pada penderita hipertensi sebanyak 16 orang (88.8\%) daripada kategori perokok sedang dan berat. Index Brinkman berhubungan dengan berbagai efek negatif dari merokok, salah satunya dalah efek pada cardiovaskular. Salah satu penelitan menyebutkan tingginya index Brinkman meningkatkan kekakuan arteri atau atheroskerosis. ${ }^{14}$

Untuk gambaran lama jangka berhenti merokok, pada hasil penelitian didapatkan yang paling banyak adalah yang telah berhenti selama $<10$ tahun $(80 \%)$.

Prevalensi hipertensi pada perokok aktif menduduki tempat pertama dibandingkan dengan tidak merokok, mantan perokok, dan perokok pasif. Berdasarkan sebuah penelitian di Sumatera Barat, kebiasaan merokok merupakan salah satu faktor resiko penyakit hipertensi. ${ }^{15}$ Sebuah penelitian lain tentang pemantauan tekanan darah 24 jam pada perokok dan bukan perokok, menunjukkan bahwa perokok mempertahankan rata-rata tekanan darah yang lebih tinggi pada siang hari dan sistolic ambulatory BP (SBP) dibanding bukan perokok, namun menunjukkan kecenderungan tekanan darah yang sama dengan bukan perokok saat pengukuran di pusat kesehatan. ${ }^{16}$ Prevalensi hipertensi paling rendah adalah pada perokok pasif yaitu sebesar 9,1\%.Seseorang yang menjadi perokok pasif, cenderung pada saat usianya dewasa akan cenderung menderita penyakit jantung koroner dan hipertensi. ${ }^{17}$

Namun tak sedikit penelitian yang menemukan kecenderungan tekanan darah yang sama atau bahkan lebih rendah pada perokok dibandingkan dengan orang yang bukan perokok. 6,18 Namun hal ini dibantah oleh sebuah penelitian tentang pemantauan tekanan darah 24 jam pada perokok dan bukan perokok. Perokok mempertahankan rata-rata tekanan darah yang lebih tinggi pada siang hari dan sistolik ambulatory $B P$ (SBP) dibanding bukan perokok, namun menunjukkan kecenderungan tekanan darah yang sama dengan bukan perokok saat pengukuran di pusat kesehatan. 19 Pada penelitian ini, pengukuran tekanan darah hanya dilakukan satu kali dengan sample yang kurang berimbang antara perokok dan non-perokok sehingga banyak terdapat faktor-faktor lain yang mempengaruhi hipertensi pada subjek.

Pada hasil penelitian, kategori perokok ringan mempunyai persentase tertinggi pada penderita hipertensi daripada kategori perokok ringan dan berat. Dilihat dari sana bahwa kategori perokok suatu subjek penelitian tidak dapat dijadikan sebagai satu faktor resiko tunggal terjadinya prehipertensi maupun hipertensi pada suatu individu. Masih terdapat banyak faktor resiko lain yang harus dikaji lebih lanjut. Selain itu perbandingan antara sample perokok ringan, sedang, dan berat tidak seimbang sehingga kurang valid untuk diinterpretasikan.

Data yang didapat dari subjek penelitian mengenai jenis rokok yang dikonsumsi menunjukkan bahwa seluruh penderita hipertensi merupakan subjek yang mengonsumsi rokok filter. $\mathrm{Hal}$ ini tidak sesuai dengan teori yang mengatakan bahwa rokok yang menggunakan filter dapat mengurangi jumlah partikel debu dari asap rokok. Filter dapat digunakan pada rokok putih, rokok kretek maupun rokok pipa, sehingga dapat mengurangi angka terjadinya beberapa penyakit akibat merokok bagi si perokok. ${ }^{3,8}$ Penelitian ini juga menunjukkan bahwa hanya 1 subjek dari seluruh subjek penelitian yang menggunakan rokok non-filter, hal ini bisa menyebabkan didapatkan angka hipertensi yang tinggi pada pengguna rokok filter.

Pada penelitian didapatkan persentase angka hipertensi tidak menunjukkan penurunan hingga pemberhentian rokok lebih dari 10 tahun. Hal ini sesuai dengan penelitian yang menunjukkan bahwa butuh waktu 10-14 tahun setelah berhenti merokok untuk menurunkan efek buruk dari rokok. Tidak ada perbedaan yang signifikan antara tingkat kematian non-perokok dan mantan perokok 10-14 tahun setelah berhenti merokok 
(Iso, 2005). Selain itu, dikatakan pada monitoring tekanan darah 24 jam menurun secara signifikan setelah berhenti merokok selama 1 minggu. ${ }^{19}$ Mantan perokok juga memiliki resiko lebih rendah mengalami kematian mendadak akibat penyakit jantung. Pada mantan perokok, durasi berhenti merokok memiliki hubungan linier yang signifikan dengan peningkatan kecepatan aliran arteri dan parameter kekakuan arteri kembali ke tingkat tidak signifikan setelah satu dekade berhenti merokok .20

Keterbatasan penelitian adalah beberapa variabel yang diteliti tidak diuraikan dan ditinjau lebih detail, yaitu: alat pengukur tekanan darah (sphygmomanometer) belum diuji sebelum digunakan untuk mengukur. Pada saat pengukuran tekanan darah tidak tekanan darah basal sampel, tekanan darah hanya diukur sebanyak 1 kali. Jumlah sample kecil dan tidak berimbang sehingga kurang mewakili kejadian sebenarnya di populasi.

\section{SIMPULAN}

Status merokok laki-laki hipertensi usia 18-64 tahun di wilayah kerja Puskesmas Susut I, kecamatan Susut 1, Bangli didapatkan cenderung merupakan perokok aktif. Mengingat kuatnya hubungan antara merokok, hipertensi dan kejadian kematian dan kesakitan akibat kardiovaskular, pihak puskesmas perlu memperhatikan pentingnya modifikasi perilaku merokok pada pasien hipertensi.

\section{Daftar Pustaka}

1. WHO. Regional Office for South-East Asia. Department of Sstainable Development and Healthy Environments. Non Comunicable Disease : Hypertension [internet]. c2011 [cited 2014 May 3]. Available from: http://www.searo.who.int/

2. Gunawan-Lany, Hipertensi. Yogyakarta: Penerbit Kanisius, 2005: 9-19.

3. Sugiharto, A. 2007. Faktor-Faktor Risiko Hipertensi Grade li Pada Masyarakat. Tesis. Semarang : Program Studi Magister Epidemiologi Program Pasca Sarjana. Universitas Diponegoro.

4. Ronny, Setiawan, Fatimah. 2010. Fisiologi Kardiovaskular. Jakarta: EGC, 26-35.

5. Nurkhalida, Warta Kesehatan Masyarakat. Jakarta: Depkes RI., 2003;19-21.
6. Umbarsemi, Rosiana, et al, 2011. Hubungan Kejadian Hipertensi dengan Merokok pada Pasien Laki-laki di UPTD Puskesmas Jakenan Kabupaten Pati. Jawa Timur: JIKK Vol 3 No.1

7. Radecki Thomas E. J.D. Hypertension: Salt is a Major Risk Factor.USA: J Cardiovasc, Feb;7(1): 2000; 5-8.

8. Suyono-Slamet, Buku Ajar Penyakit Dalam Jilid II. FKUI, Jakarta: Balai Pustaka, 2001; 253, 454459,463-464.

9. Hull-Alison, Penyakit Jantung, Hipertensi, dan Nutrisi. Jakarta: Bumi Aksara, 1996; 18,29.

10. Price, S.A. \& Wilson L.M., 2006. Patofisiologi: Konsep Klinis Proses-Proses Perjalanan Penyakit, 6th ed. Gangguan Sistem Kardiovaskular. Jakarta: Penerbit Buku Kedokteran EGC, 517-688.

11. Sani-A, 2010. Diakses tanggal 17 September 2014. Bahaya Rokok bagi si Pasif. http://health.kompas.com. Jakarta

12. Zulkeflie NASB, 2010. Diakses tanggal 5 September 2014. Pengaruh Tekanan Darah Pada Perokok Di Kalangan Mahasiswa Lelaki Angkatan 2007 Fakultas Kedokteran Universitas Sumatera Utara. http://repository.usu.ac.id. Medan

13. Sitepoe, M., 1997. Usaha Mencegah Bahaya Merokok. Jakarta: Gramedia.

14. Bustan, M.N., 2000. Epidemiologi Penyakit Tidak Menular. Jakarta: Rineka Cipta.

15. Aditama, Tjandra Yoga, 2006. Tuberkulosis, Rokok Dan Perempuan. FKUI, Jakarta.

16. Sherwood, L., 2001. Fisiologi Manusia dari Sel ke Sistem. Pembuluh Darah dan Tekanan Darah. Jakarta: Penerbit Buku Kedokteran EGC, 297340.

17. Irza,S, 2009. Diakses tanggal 15 September 2014. Analisis Faktor Resiko Hipertensi pada Masyarakat Nagari Bungo Tanjung Sumatera Barat. . http://repository.usu.ac.id. Medan

18. Murbawani, EA, 2002. Diakses tanggal 15 September. Nikotin Rokok Tingkatkan Denyut Jantung. http://www.suaramerdeka.com.html

19. Widjaja, et all. 2013. Prehypertension and Hypertension among young Indonesian adults at a primery health care in arural area. Jakarta: Med J Indones; 22:(1).

20. YogiantoroMm. Hipertens Esensial Dalam Buku Ajar IImu Penyakit Dalam Jilid I edisi IV . Jakarta : FK UI 2006.

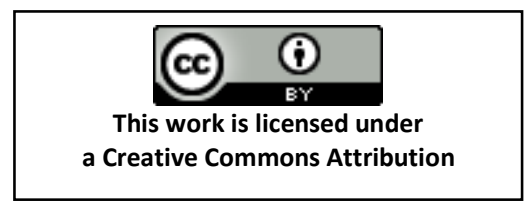

